\title{
ANATOMICAL RELATION BETWEEN THE RECURRENT LARYNGEAL NERVE AND THE THYROID GLAND
}

\author{
By \\ IkUichtro HIROTO. M.D., Minoru HIRANO. M.D. \\ Yorikazu TOYOZUMI. M.D. Fumitake TAKASE. M.D. \\ Seiro TAKASE. M.D., Yoshinori YATAKE. M.D. \\ From the Department of Otolaryngology, School of Medicine, \\ Kurume University (Director: Prof. Ikuichiro Hiroto.)
}

Fourty-seven adult cadaver larynges with thy roid glands were dissected under a binocular microscope, in order to illustrate the extralaryngeal division of the recurrent laryngeal nerve and its relation to the thyroid gland and the inferior thyroid artery.

Results were summarized as followes :

(1) The recurrent laryngeal nerves, in all cases except one, were divided prior to arriving the lower margin of the cricopharyngeal muscle where the nerve enteredinto the larynx. A type of two divisions was of und in $67 \%$ of examined 94 nerves, three divisions in $27 \%$ and four in $5 \%$. In most cases the site of the division was within $1.5 \mathrm{~cm}$ below the lower margin of the cricopharyngeal muscle.

(2) In any type of the nerve division the anterior branch always consisted of motor fibers and the posterior branch was composed of sensory fibers which joined with a branch of the superior laryngeal nerve and composed Galen's anastomosis. When the nerve was divided into three branches, the middle branch was in many cases a motor nerve which innervated the adbuctor muscle, and occationally it was found a sensory one. In cases which the nerve was divided into four branches, the antero-mediate branch was a motor nerve which innervated the abductor muscle and the posteromediate was a sensory one,

(3) The recurrent lanryngeal nerve was found to run adjacent to the thyroid gland in $83 \%$ of all cases and apart from the gland in only $17 \%$. In most cases the recurrent laryngeal nerve was in the close position to the lower two thirds of the thyroid gland.

(4) The recurrent layngeal nerve was situated anteriorly to the inferior thyroid artery in $12 \%$ of all cases and posteriorly in $21 \%$. In $67 \%$ of cases, the nerve ran between branches of the artery and was drawn nearer to the thyroid gland.

\section{喉頭神経損傷に関する手術解剖学的研究}

—甲状腺と反回神経との関倸について—

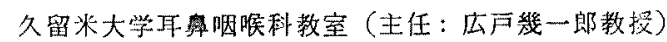

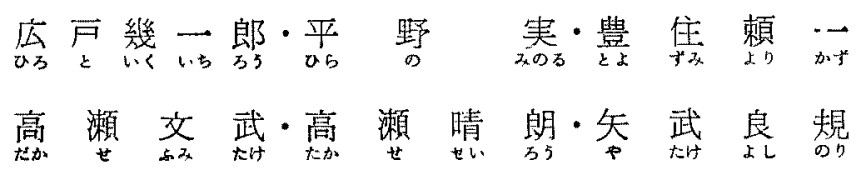

I. 緒

反回神経麻㾇の原因として甲状腺手術時の神経損稘が 最も多いことは周知の事実である。この場合，腫疸の浸潤
のため止をを得ず反回神経を切断することもあるが，神 経に対して不用意に損賃が加えられる場合も少くない。 反回神経麻瘦は，榎声あるい性吸障害を招来し，患者 
の社会生活に少からざる支障をきたすものであるから， 原疾患の治療を妨げない限り，その損傷を避ける上ら努 力すべきである.そのためには反回神絴の走行に関する 充分なる局所解剖学的知識が必要である。

従来, 反回神経乞のもの関する解剖学的研究は極め て多いが，反回神経と甲状腺との位置的関係についての 研究，特にこれを外科的立場に立つて詳細に検討した報 告は意外に少い，我々は頸部外科の立場から反回神経と 甲状腺および下甲状腺動脈之の位置的関倸火ついて局所 解剖学的検索を行い，若干の知見を得たので報告する。

\section{II. 研究方法}

本学系統解剖ならびに病理解剖学教室より提供された 成人, 男屍 28 , 女屍 19 , 計 47 体 94 側々ついて解剖学 的観察を行つた。いづれる䐅頭および甲状腺に疾患を認 めない正常例である. 先づ食道, 喉頭, 気管および甲状 腺を，上下甲状腺動脈，反回神経枋よび上䐅頭神経をつ けたまま一埤として取り出した後，立体双眼影微鏡下に 剥離観察して, 反回神経の走行, 下甲状腺動脈の走行, 神経之動脈和よび甲状腺との位置的関係等について検討 した. 又, 反回神経が分岐している場合, 各分枝が堠頭 内のどの部分にどのよ5に分布するかをも追求検討し た.

\section{III. 反回神経の走行と分岐について}

反回神経は食道の 前面で気管の 後外部に接して上行 し，数本の食道枝招よび気管枝を分枝した後，下㬋頭神 释として搌頭内に入るが，多くの場合搌頭外で既に分㞳 している.ここに云う㬋頭内とは輸状咽頭筋下縁より上
方を意味しているが，甲状腺の手術に際して手術操作が 加わるのは輪状咽頭筋下縁より下方であるので，ここで は下喉頭神経の膜頭外分岐について述べる.

下唉頭神経の唤頭外分岐には次の 4 つの型がある（四 1).

（1）無分吱：喉頭外では分岐しないもの.

（2）二分岐：前後の二枝に分岐するもの.

前枝は輸状甲状筋を除くすべての内哄頭筋に分布する。 運動枝である。

後枝は，上㜊頭神経内枝と所㯰 Galen 吻合を形成し， 啒頭筋には分布しない，即ち知敩枝である.

(3) 三分岐：前中後の三枝に分岐するすので，各枝 を前枝，中枝，後枝と称することにする．前枝は内唉頭 筋に分布する運動枝であり，後枝はGalen 吻合を非成， する知覚枝である，中枝は運動枝である場合と吻合枝で

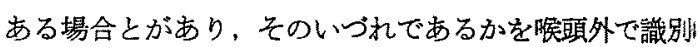
することは多くの場合困難である，中枝が運動枝である， 場合は，これは後輪状披裂筋を支配する.

（4）四分岐：四枝に分岐するもので，前方上りそれ， それ前枝，第一中枝，第二中枝，後枝之称することにす る. 前二者は運動枝で前枝は甲状披裂筋，㑡輪状披裂 筋，披裂筇を，即ち声帯内転筋すへてを，第一中枝は声 带外転笳即ち後輪状披裂筇を支配する，後二者は Galen 吻合枝, 即ち知覚枝である.

なお，喉頭外で三分岐拉よび四分岐をしている場合， 䐅頭内で，更に前枝上り後輪状披裂筋に分布する小枝を 分つていることがあるが，喉頭内分岐の詳細については

Fig. 1 Types of extralaryngeal division of the recurrent laryngeal nerve

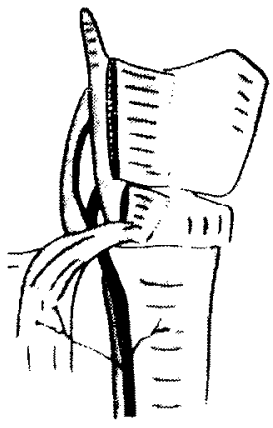

(1)

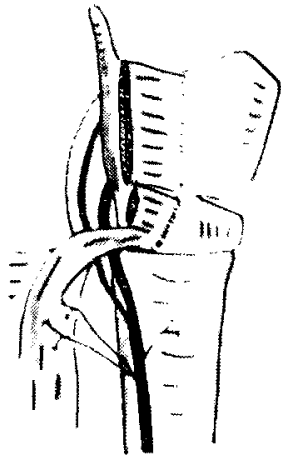

(2)

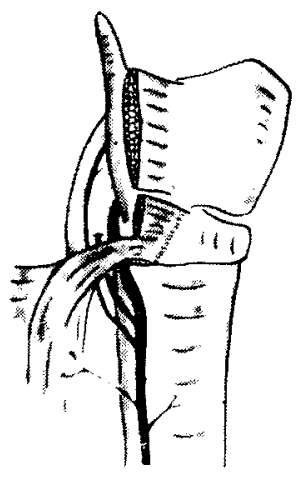

(3)

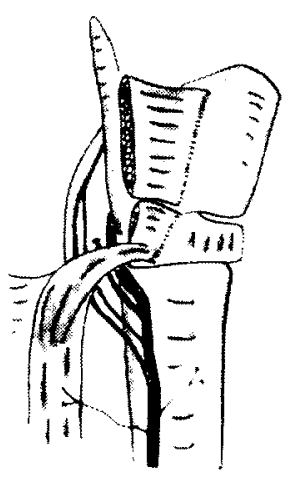

$(4)$

(1) not divided

(3) divided into three branches

(2) divided into two branches

(4) divided into four branches 
ここでは触れない。

以上 4 つ分岐型式の出現頻度を性別，左右別にみる と表1の如くである.性别, 左右別に著明な差はなく， 二分岐が最も多くて $67 \%$ ，以下 3 分岐が $27 \%$ ，四分岐 が5\%で，無分岐は $1 \%$ に過ぎない.

次にこれらの岍頭外分肢はどの場所で行われているか を検討する．輪状咽頭筋下縁からこの分岐部迄の距離を
計測すると表 2 の如くになる．即ち，喉頭外分岐は輪状 咽頭筋の下緑より $0.6 〜 1.0 \mathrm{~cm}$ 牤よび 1.1〜 1.5cm 下方 で行はれる場合が最も多く，雨者を合せると63\%とな り，過半数を占める. $0.5 \mathrm{~cm}$ 以下または $2.1 \mathrm{~cm}$ 以上下 万で分岐するものは最も少く，僅が $12 \%$ に過ざない， 上述の分岐形式，部位汇関して性著しい男女差，左右差 は認められない。

Table. 1. Number of extralaryngeal division of recurrent laryngeal nerve ( 94 nerves)

\begin{tabular}{|c|c|c|c|c|c|c|c|c|c|}
\hline \multirow{2}{*}{$\begin{array}{l}\text { Number } \\
\text { of } \\
\text { divisions }\end{array}$} & \multicolumn{3}{|c|}{ male } & \multicolumn{3}{|c|}{ female } & \multicolumn{3}{|c|}{ total } \\
\hline & right & left & total & right & left & total & right & left & total \\
\hline no division & 0 & 1 & $(2 \%)$ & 0 & 0 & $\left(\begin{array}{c}0 \\
0 \%\end{array}\right.$ & 0 & $(2 \%)$ & $\left(\begin{array}{c}1 \\
1 \%\end{array}\right)$ \\
\hline two & 19 & 19 & $\begin{array}{c}38 \\
(68 \%)\end{array}$ & 12 & 13 & $\begin{array}{c}25 \\
(66 \%)\end{array}$ & $\begin{array}{c}31 \\
(66 \%)\end{array}$ & $\begin{array}{c}32 \\
(68 \%)\end{array}$ & $\begin{array}{c}63 \\
(67 \%)\end{array}$ \\
\hline three & 8 & 6 & $\begin{array}{c}14 \\
(25 \%)\end{array}$ & 6 & 5 & $\begin{array}{c}11 \\
(29 \%)\end{array}$ & $\begin{array}{c}14 \\
(30 \%)\end{array}$ & $\begin{array}{c}11 \\
(23 \%)\end{array}$ & $\begin{array}{c}25 \\
(27 \%)\end{array}$ \\
\hline four & 1 & 2 & $(5 \%)$ & 1 & 1 & $\left(\begin{array}{c}2 \\
5 \%\end{array}\right.$ & $\left(\begin{array}{c}2 \\
4 \%\end{array}\right)$ & $(6 \%)$ & $\left(\begin{array}{c}5 \\
(5 \%)\end{array}\right.$ \\
\hline total & 28 & 28 & 56 & 19 & 19 & 38 & 47 & 47 & 94 \\
\hline
\end{tabular}

Table. 2. Distance between the lower margine of the cricopharyngeal muscle and the location of extralaryngeal division of the recurrent laryngeal nerve ( 93 nerves)

\begin{tabular}{|c|c|c|c|c|c|c|c|c|c|}
\hline \multirow{2}{*}{$\begin{array}{c}\text { Distance } \\
\text { in } \\
\mathrm{cm}\end{array}$} & \multicolumn{3}{|c|}{ male } & \multicolumn{3}{|c|}{ female } & \multicolumn{3}{|c|}{ total } \\
\hline & right & left & total & right & left & total & right & left & total \\
\hline less than 0.5 & 4 & 2 & $(11 \%)$ & 4 & 1 & $\begin{array}{c}5 \\
(13 \%)\end{array}$ & $(18 \%)$ & $\left(\begin{array}{c}3 \\
(7 \%)\end{array}\right.$ & $(12 \%)$ \\
\hline $0.6 \sim 1.0$ & 10 & 11 & $\begin{array}{c}21 \\
(38 \%)\end{array}$ & 7 & 6 & $\begin{array}{c}13 \\
(34 \%)\end{array}$ & $\begin{array}{c}17 \\
(36 \%)\end{array}$ & $\begin{array}{c}17 \\
(37 \%)\end{array}$ & $\begin{array}{c}34 \\
(37 \%)\end{array}$ \\
\hline $1.1 \sim 1.5$ & 5 & 8 & $\begin{array}{c}13 \\
(24 \%)\end{array}$ & 4 & 8 & $\begin{array}{c}12 \\
(32 \%)\end{array}$ & $(19 \%)$ & $\begin{array}{c}16 \\
(35 \%)\end{array}$ & $\begin{array}{c}25 \\
(27 \%)\end{array}$ \\
\hline $1.6 \sim 2.0$ & 4 & 3 & $\begin{array}{c}7 \\
(13 \%)\end{array}$ & 4 & 1 & $\begin{array}{c}5 \\
(13 \%)\end{array}$ & $\begin{array}{c}8 \\
(18 \%)\end{array}$ & $\left(\begin{array}{c}4 \\
9 \%\end{array}\right)$ & $(13 \%)$ \\
\hline more than 2.0 & 5 & 3 & $\begin{array}{c}8 \\
(14 \%)\end{array}$ & 0 & 3 & $(8 \%)$ & $(11 \%)$ & $\begin{array}{c}6 \\
(13 \%)\end{array}$ & $\begin{array}{c}11 \\
(12 \%)\end{array}$ \\
\hline total & 28 & 27 & 55 & 19 & 19 & 38 & 47 & 46 & 93 \\
\hline
\end{tabular}




\section{IV 反回神経と甲状腺との 位置的関係について}

反回神経と甲状腺との位㯰的関係は下記の 3 型に区分 される(図2).

（1）反回神経が甲状腺の裹側を走るもの.

（2）反回神経が甲状腺の後縁に接して走るもの.

（3）反回神経が甲状腺の後縁上り離れて走るもの.

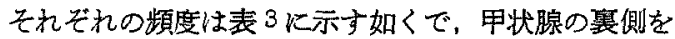
走るものが $51 \%$ で最も多く，甲状腺の後縁に接する場

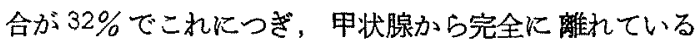
場合は僅か 17\% である。この傾向は男女，左右の差な く認められるが，特に左側では反回神経が甲状腺に密接 している傾向が強い。
反回神経と甲状腺との位置的関俰は，甲状腺の大き さ，反回神経自身の走行により決定されるが，反回神経 の走向に後述の如く，神経が下甲状腺動脈，時には同名 静脈の分岐間に介在するか否か，即ち血管之の位固的関 係が大きく影響し，分枝間に介在する場合には，血管に より甲状腺の方へ牽引された位置をとる。

甲状腺葉を上下に三等分して，上中下いずれの高さ で，反回神経が皖頭内に入るかを観察すると表 4 の如き 成績である．即ち男女，左右の別なく，神释の喉頭内進 入部が腺葉の中 $1 / 3$ 部の高さにあるものが圧倒的に多 く，全体の $82 \%$ を占め，上 $1 / 3$ 部のものは $11 \%$ 下 $1 / 3$ 部のわの7\%に過ぎない，換言すれば，手術に際しては 甲状腺葉の下方 $2 / 3$ の剝離を慎重に行らべきであって

Fig. 2 Relation of the recurrent laryngeal nerve to the thyroid gland.

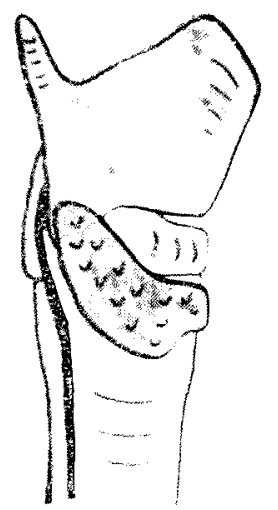

(1)

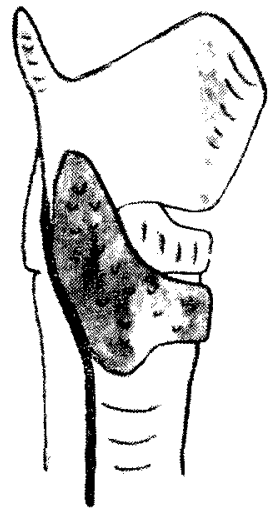

(2)

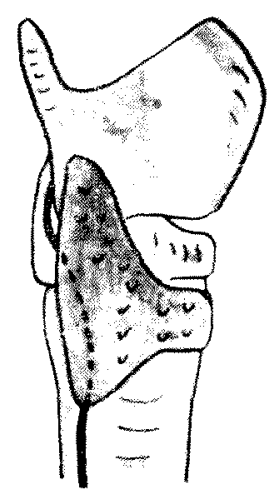

(3)

(1) apart from the gland

(3) adjacent to the postero-medial surface

Table. 3. Relation of the recurrent laryngeal nerve to the thyroid gland. (94 nerves)

\begin{tabular}{|c|c|c|c|c|c|c|c|c|c|}
\hline & & male & & & emale & & & total & \\
\hline & right & left & total & right & left & total & right & feft & total \\
\hline $\begin{array}{l}\text { apart from } \\
\text { the gland }\end{array}$ & 8 & 2 & $\begin{array}{c}10 \\
(18 \%)\end{array}$ & 3 & 3 & $(16 \%)$ & $(23 \%)$ & $(11 \%)$ & $\begin{array}{c}16 \\
(17 \%)\end{array}$ \\
\hline $\begin{array}{l}\text { adjacent to the } \\
\text { posterior margine } \\
\text { of the gland }\end{array}$ & 9 & 10 & $\begin{array}{c}19 \\
(34 \%)\end{array}$ & 8 & 3 & $(29 \%)$ & $(36 \%)$ & $\begin{array}{c}13 \\
(28 \%)\end{array}$ & $\begin{array}{c}30 \\
(32 \%)\end{array}$ \\
\hline $\begin{array}{l}\text { adjacent to the } \\
\text { postero-medial } \\
\text { surface of gland }\end{array}$ & 11 & 16 & $\begin{array}{c}27 \\
(48 \%)\end{array}$ & 8 & 13 & $\begin{array}{c}21 \\
(55 \%)\end{array}$ & $\begin{array}{c}19 \\
(40 \%)\end{array}$ & $\begin{array}{c}29 \\
(62 \%)\end{array}$ & $\begin{array}{c}48 \\
(51 \%)\end{array}$ \\
\hline total & 28 & 28 & 56 & 19 & 19 & 38 & 47 & 47 & 94 \\
\hline
\end{tabular}


Table. 4. Portion of the thyroid gland corresponding to the place where the recurrent laryngeal nerve enters into the larynx.

\begin{tabular}{|c|c|c|c|c|c|c|c|c|c|}
\hline & \multicolumn{3}{|c|}{ male } & \multicolumn{3}{|c|}{ female } & \multicolumn{2}{|r|}{ total } & \multirow[b]{2}{*}{ total } \\
\hline & right & ieft & total & right & left & total & right & left & \\
\hline upper third & 0 & 4 & $\begin{array}{c}4 \\
(7 \%)\end{array}$ & 4 & 2 & $\left(\begin{array}{c}6 \\
(16 \%)\end{array}\right.$ & $\left(\begin{array}{c}4 \\
(9 \%)\end{array}\right.$ & $\begin{array}{c}6 \\
(13 \%)\end{array}$ & $\begin{array}{c}10 \\
(11 \%)\end{array}$ \\
\hline middle third & 24 & 23 & $\begin{array}{c}47 \\
(84 \%)\end{array}$ & 14 & 16 & $\begin{array}{c}30 \\
(79 \%)\end{array}$ & $\begin{array}{c}38 \\
(81 \%)\end{array}$ & $\begin{array}{c}39 \\
(83 \%)\end{array}$ & $\begin{array}{c}77 \\
(82 \%)\end{array}$ \\
\hline lower third & 4 & 1 & $\left(\begin{array}{c}5 \\
9 \%\end{array}\right)$ & 1 & 1 & $\left(\begin{array}{c}2 \\
(5 \%)\end{array}\right.$ & $\begin{array}{c}5 \\
(11 \%)\end{array}$ & $\left(\begin{array}{c}2 \\
4 \%\end{array}\right)$ & $\left(\begin{array}{c}7 \\
(7 \%)\end{array}\right.$ \\
\hline total & 28 & 28 & 56 & 19 & 19 & 38 & 47 & 47 & 94 \\
\hline
\end{tabular}

Table. 5. Distance from the lower end of the thyroid to the place where the recurrent laryngeal nerve enters into the larynx. ( 94 nerves)

\begin{tabular}{|c|c|c|c|c|c|c|c|c|c|}
\hline \multirow{2}{*}{$\begin{array}{c}\text { Distance } \\
\text { in } \\
\mathrm{cm}\end{array}$} & \multicolumn{3}{|c|}{ male } & \multicolumn{3}{|c|}{ female } & \multicolumn{3}{|c|}{ total } \\
\hline & right & left & total & right & left & total & right & left & total \\
\hline $1.0 \sim 1.5$ & 3 & 3 & $(11 \%)$ & 2 & 5 & $\left(\begin{array}{c}7 \\
(18 \%)\end{array}\right.$ & $(11 \%)$ & $\begin{array}{c}8 \\
(17 \%)\end{array}$ & $\begin{array}{c}13 \\
(14 \%)\end{array}$ \\
\hline $1.6 \sim 2.0$ & 10 & 5 & $\begin{array}{c}15 \\
(27 \%)\end{array}$ & 8 & 6 & $\begin{array}{c}14 \\
(37 \%)\end{array}$ & $\begin{array}{c}18 \\
(38 \%)\end{array}$ & $\begin{array}{c}11 \\
(23 \%)\end{array}$ & $\begin{array}{c}29 \\
(31 \%)\end{array}$ \\
\hline $2.1 \sim 2.5$ & 9 & 13 & $\begin{array}{c}22 \\
(39 \%)\end{array}$ & 3 & 4 & $(18 \%)$ & $\begin{array}{c}12 \\
(26 \%)\end{array}$ & $\begin{array}{c}17 \\
(36 \%)\end{array}$ & $\begin{array}{c}29 \\
(31 \%)\end{array}$ \\
\hline $2.6 \sim 3.0$ & 6 & 5 & $\begin{array}{c}11 \\
(20 \%)\end{array}$ & 4 & 2 & $\begin{array}{c}6 \\
(16 \%)\end{array}$ & $\begin{array}{c}10 \\
(21 \%)\end{array}$ & $\begin{array}{c}7 \\
(15 \%)\end{array}$ & $(18 \%)$ \\
\hline more than 3.1 & 0 & 2 & $\left(\begin{array}{c}2 \\
4 \%\end{array}\right)$ & 2 & 2 & $\begin{array}{c}4 \\
(11 \%)\end{array}$ & $(4 \%)$ & $\left(\begin{array}{c}4 \\
(9 \%)\end{array}\right.$ & $(6 \%)$ \\
\hline total & 28 & 28 & 56 & 19 & 19 & 38 & 47 & 47 & 94 \\
\hline
\end{tabular}

この部が反回神経と最も関係が樑い。

これを別の観点から检討すると表 5 の如くになる，即 5 , 甲状腺葉下端加 5 , 下腒頭神経の胒頭内進入部迄の 距離を計測し，性別，男女別に示したるのであるが，こ れによると，甲状腺葉下緑よn，6〜2.0 cm および 2.1

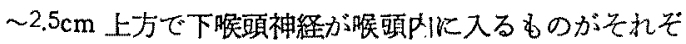
れ31\%で最も多く，2.6〜3.0 cm の場合がこれに次いで いる，このことは，甲状腺葉下端より上方 $3.0 \mathrm{~cm}$ ，特に $2.5 \mathrm{~cm}$ までの部分が反回神経と口，関係が密接で，手術時 注意を要することを示している.

\section{V. 下甲状腺動脈の走行とその分岐について}

甲状腺手術に際しては甲状腺動脈に対する処置が必要
なことは云うまでもない、下甲状腺動脈は，鎖骨下動脈 の枝である甲状頸動脈か,ら分枝し，総橮動脈，内頸静 脈，迷走神経和よび横滆膜神経の後方を内上方へ向つて 走り、途中，気管扣よび食道に枝を与えた後，甲状腺葉 後縁下部に達する。そして腺外で2ないし4本の枝に分 れて，甲状腺葉下部加腺の内および外側面に分布進入 している. 又この分岐の型式には図 3 に示す如く，二分 岐，三分收，四分岐の3 型が認められ，各々の頻度は表 6 に示す如くである。性別，左右別を問わず三分岐が $53 \%$ で最も多く，二分岥は $37 \%$ ，四分岐は $10 \%$ で最る 少い。 
Fig. 3 Types of extraglandular division of the inferior thyroid artery.

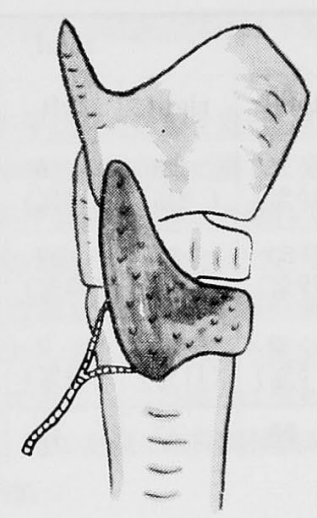

(1)

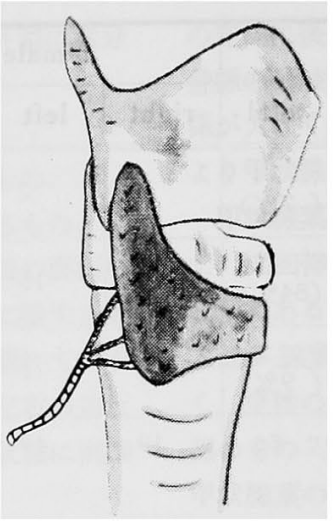

(2)

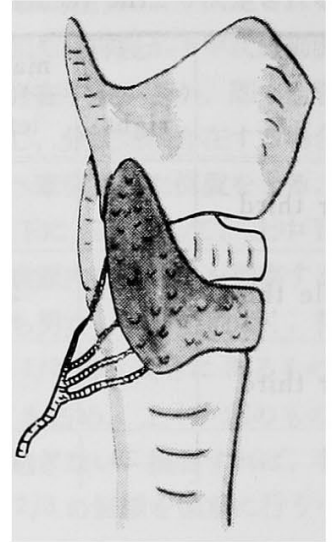

(3)

(1) divided into two branches

(2) divided into three branches

Table. 6. Number of extraglandular divisions of the inferior thyroid artery ( 94 arteries)

\begin{tabular}{|c|c|c|c|c|c|c|c|c|c|}
\hline \multirow{2}{*}{ Number } & \multicolumn{3}{|c|}{ male } & \multicolumn{3}{|c|}{ female } & \multicolumn{3}{|c|}{ total } \\
\hline & right & left & total & right & left & total & right & left & total \\
\hline two & 9 & 13 & $\begin{array}{c}22 \\
(39 \%)\end{array}$ & 7 & 6 & $\begin{array}{c}13 \\
(34 \%)\end{array}$ & $\begin{array}{c}16 \\
(34 \%)\end{array}$ & $\begin{array}{c}19 \\
(40 \%)\end{array}$ & $\begin{array}{c}35 \\
(37 \%)\end{array}$ \\
\hline three & 15 & 10 & $\begin{array}{c}25 \\
(45 \%)\end{array}$ & 12 & 13 & $\begin{array}{c}25 \\
(66 \%)\end{array}$ & $\begin{array}{c}27 \\
(57 \%)\end{array}$ & $\begin{array}{c}23 \\
(49 \%)\end{array}$ & $\begin{array}{c}50 \\
(53 \%)\end{array}$ \\
\hline four & 4 & 5 & $(16 \%)$ & 0 & 0 & $\left(\begin{array}{c}0 \\
(0 \%)\end{array}\right.$ & $\left(\begin{array}{c}4 \\
(9 \%)\end{array}\right.$ & $\begin{array}{c}5 \\
(11 \%)\end{array}$ & $(10 \%)$ \\
\hline total & 28 & 28 & 56 & 19 & 19 & 38 & 47 & 47 & 94 \\
\hline
\end{tabular}

IV. 反回神経と下甲状腺動脈との 位置的関係について

下甲状腺動脈は甲状腺に入る前に反回神経と交叉する が，交叉部における両者の位置的関俰は次の 3 型に分け られる(図4).

（1）神䋊が動脈の前を走るもの.

（2）神経が動脈の後を走るもの.

(3) 神経が動脈の分枝の間を走るもの.
これら 3 型の頻度は表 7 亿示す如くで男女, 左右の別 なく，神経が動脈分枝の間を走る場合が最も多く，67\% を占めている．動脈の後を走る場合が，21\%でこれに 次き，前を走る場合は $12 \%$ で最も少い，動脈分枝間を 神経が 走る場合が 最も多いことは注目すべき事実であ ク，図 5 に示す如く，動脈分枝部の位置により，反回神 経が甲状腺の内後方に密着する如く牽引されている場合 も少くない。 
Fig. 4 Relation of the recurrent laryngeal nerve to branches of the inferior thyroid artery.

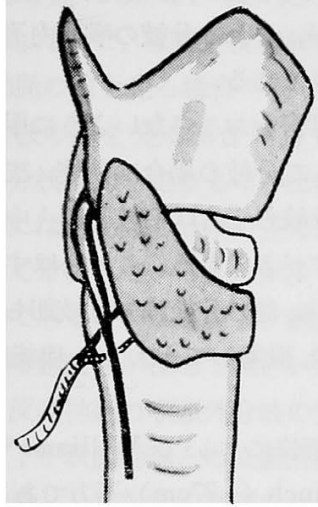

(1)

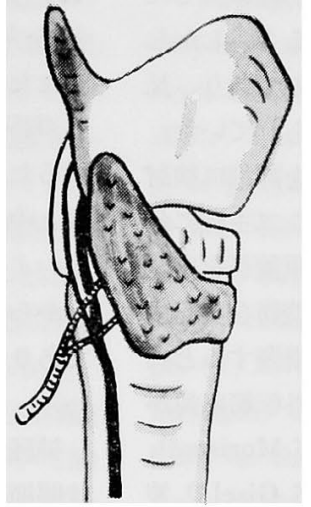

(2)

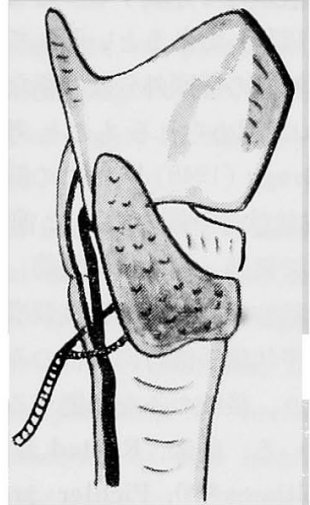

(3)

(1) The nerve is situated anteriorly to the artery.

(2) The nerve is situated posteriorly to the artery.

(3) The nerve is situated between branches of the artery.

Table. 7. Relation of the recurrent laryngeal nerve to branches of the inferior thyroid artery (94 nerves)

\begin{tabular}{|c|c|c|c|c|c|c|c|c|c|}
\hline & \multicolumn{3}{|c|}{ male } & \multicolumn{3}{|c|}{ female } & \multicolumn{3}{|c|}{ total } \\
\hline & right & left & total & right & left & total & right & left & total \\
\hline anterior & 2 & 3 & $\left(\begin{array}{c}5 \\
(9 \%)\end{array}\right.$ & 4 & 2 & $\begin{array}{c}6 \\
(16 \%)\end{array}$ & $(12 \%)$ & $\begin{array}{c}5 \\
(11 \%)\end{array}$ & $\begin{array}{c}11 \\
(12 \%)\end{array}$ \\
\hline posterior & 5 & 7 & $\begin{array}{c}12 \\
(21 \%)\end{array}$ & 3 & 5 & $\begin{array}{c}8 \\
(21 \%)\end{array}$ & $\begin{array}{c}8 \\
(17 \%)\end{array}$ & $\begin{array}{c}12 \\
(26 \%)\end{array}$ & $\begin{array}{c}20 \\
(21 \%)\end{array}$ \\
\hline between & 21 & 18 & $\begin{array}{c}39 \\
(70 \%)\end{array}$ & 12 & 12 & $\begin{array}{c}24 \\
(63 \%)\end{array}$ & $\begin{array}{c}33 \\
(70 \%)\end{array}$ & $\begin{array}{c}30 \\
(64 \%)\end{array}$ & $\begin{array}{c}63 \\
(67 \%)\end{array}$ \\
\hline total & 28 & 28 & 56 & 19 & 19 & 38 & 47 & 47 & 94 \\
\hline
\end{tabular}

Fig. 5 When the recurrent laryngeal nerve runs between branches of the inferior thyroid artery, the nerve is drawn nearer to the thyroid gland.
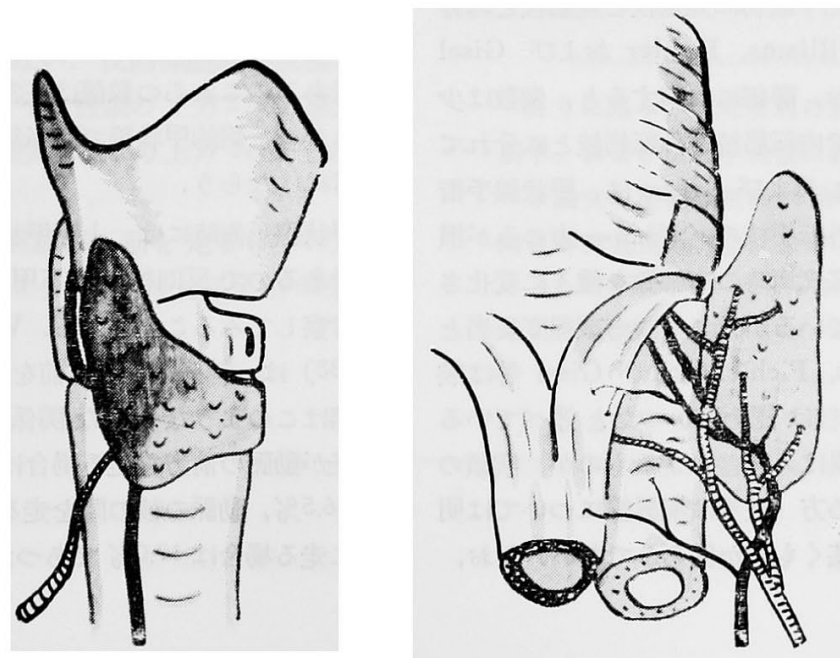


\section{VII．総括ならびに考按}

下倨頭神経が㩔頭外で分伎することを最初垠告した 人は Meckel (1832) であるといわれている4)。乙かし 一般には下喉頭神経の脆頭外分肢は稀なるのであり，刃 多くは右側のみに認められるものと考光られていた。 King および Gregg (1948)1)はこの問題を詳細に檢討 し反回神経は 輪状䧈骨下縁の高さで前後の二主枝に分 れ，前枝は甲状披裂筋，䚋輸状披裂纷，喉頭蓋筋を支配

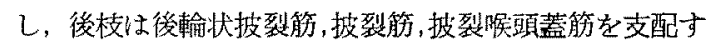
ると述べ，更に甲状腺手術時に前校のみを損傷すると内

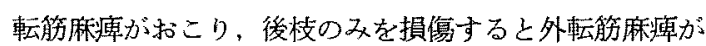

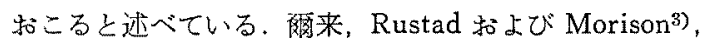
Morison ${ }^{4)}$, Williams 2) 6), Pichler 物よび Gisel 9) 等

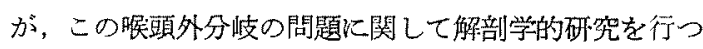
ている. Rustad および Morison が䐅頭外で分岐した 2 ないし6本の枝には外転筋支配のものと内転筋 支配 のものとがあると述べているのに対して Williams, Pichler 小よび Gisel はこれ等の枝は 知覚枝と運動枝 とに分かれるのであるとして対立した見解を示してい る. 又，搌頭外分岐は Morison に上れば 200 体側中 43 \%に認められるに過ぎないが, Williams や Pichler 扣よび Gisel は 100 体側中すべてに認められるとして いる.

我々の 94 体側の检索成續に上れば，下倨頭神経の 67 \%は知党枝 (Galen 吻合枝) と運動枝とに二分して倨頭 内に入るが，その他に知覚枝又は運動枝のいづれかが更 に二つに分岐して三分岐型式を示すものが $27 \%$ ，两者 とも分岐して四分岐型式を示寸 ものが $5 \%$ に認められ る. 又，胒頭外で全く分岐しないるのは僅か $1 \%$ に過ぎ ない：この所見は，殆んどすべての例に喉頭外分岐を認 めること，反回神絽は先ず最初に知党枝と運動枝之に分 岐するという点で, Williams, Pichler 怙よび Gisel の成績と一政する。な゙，詳細に检索すると，例数は少 いが，運䡛枝が堠頭外で内転筋枝と外転筇枝とに分れて いる場合むるる。 King 特上び Gregg は，甲状腺手術 時に内転筇枝あるいは外転筋枝のいずれか一方のみが損 貨され，これが反回神経麻瘦時の声带像を種々飞变化さ せる一因となるといつているが，この説も或程度桑当と 考えられる. Williams, Pichler および Gisel 等は搌 頭外での 外轱筋への 分枝は認めなかつたと述べている が，我々の成績との美異は人種差によるものか，搌頭の 外と内之の境界線の定め方（彼等恃境界線については明 記していない）の差に基くものか明らかでない.なお，
Ktng 怙よび Gregg, Rustad 拉よび Morison 等は下 㗹頭神経は知頭外で常に内転筇枝と外転筋枝とに分れる と述べているが，これは分枝の琁頭内追求が不分分であ つたための誤りである.

声带の運動障害を扣こさないよらに甲状腺手術を完遂 するためには，二分肢の場合は前枝，三分岐の場合は前 枝と中枝，4 分岐の場合は前枝と第 1 中枝を特に損稘し ないよう注意すべきである、これらはすべて運動枝であ るからであるが，他の分枝は知覚枝即ら Galen 吻合枝 でありたとえ損傷しても大した機能障害はおこらな い.

神経分岐の部位について Williams ${ }^{6)}$ は通常輸状甲 状関節の $1 / 2$ inch $(1.27 \mathrm{~cm})$ 下方であると述へ，我々 の成績に近い值を示している，我々は翰状咽頭筋下縁と 反回神経との交叉部を基準として計測しているが，多く の場合この基準点より下方 $1.5 \mathrm{~cm}$ 以内で分岥すること は前述した如くである。

反回神経と甲状腺との位置的関倸について詳細に检颜 した報告はなく，単に反回神経は甲状腺の後方を走ると いら記載をみる程度である. 我々の成績では, 神絽が甲 状腺葉の裏側，页は後緑厄接して走る場合は全例の81 \%を占めており，これらの例に打いては甲状腺をたとえ 被膜に直接して剥離していつても必ず反回神経化触れさ るを得ない，しかもこの上うな位䈯的関保は左側とより 多く認められるものである. 以上は正常の場合であるの で，腫大した病的甲状腺の場合には，殆んど 100\%にお いて反回神経俚甲状腺に接触しているものと考之て和か ねばならない、ここで，反回神絟は甲状腺のどの部分と特 に密接しているかということが問題となるが，我々の観 察成績では，大多数 $(89 \%)$ が甲状腺葉の下 $2 / 3$ 部であ る、換言すれぱ，甲状腺葉下端から上方 $2.5 \mathrm{~cm}$ あるい は $3.0 \mathrm{~cm}$ 以内の部分に特に 注意せるね゙ならないといら 事である.これらの数值は正常甲状腺についてのむので あるから，病的甲状腺では当然翼つた值となるが一応の 参考にはならら。

甲状腺手術時には，上下甲状腺動脈を結紮するのが普 通であるので反回神経と下甲状腺動脈との関係につい て考察してみることとする. Woelfler (1879), Kocher (1883) は，神経は毁脈の前を走ると述へているす）が， 实際はこのような簡単な関係ではない，Morisonすは は 神絽が動哌の前方を走る場合は $27.5 \%$ ，後方を走る場合 は $46.5 \%$ ，動脈の枝の間を走る場合は $26.0 \%$ ，動脈と平 行に走る場合は $17.0 \%$ であつたと報告し，Williams ${ }^{(i)}$ 
は神程が 動脈主幹の前を走る場合は $32 \%$ ，後を走る場 合は $68 \%$ であると述べている．我々は下甲状腺動眽の 分岥態度を検諲した上で，動脈と反回神経との関保を追 求し，神経が動脈の前を走る場合 $12 \%$ ，後を走る 場合 $21 \%$ ，動眽の分枝の間を走る場合 $67 \%$ とい5成績を得 た. 神経が動脈分枝の間を走るものが王倒的に多く，し かもそれらの中には，動脈の分枝の股の部分が神経を甲 状腺の方へ向つて率引しているものが少くないことは, 注目すべき事実である，かかる場合，動脈の処置に際し て神経を損傷する危険性が亟方て大きいからである。

以上我々は，反回神経の咲頭外分岐の実熊，反回神経 と甲状腺括よび下甲状腺動脈之の位置的関係について論 じたが，ここに示した解剖学的事項を念頭に执いて甲状 腺手術に䧗めば，不必要な反回神経損賃は或程度避けら れるものと考觉る. 又, 反回神経の搌頭外分岥の諸形式 は，甲状腺手術後の皖頭麻源に打ける声带像の多樣性を 説明する一因子となり得ると考劣られる。

\section{VIII. 結 語}

正常成人屍体男 28 体，女 19 体，計 47 体 94 側以つい て, 反回神経の胒頭外分岥, 反回神経と甲状腺洛よび下 甲状腺動眽との関俰を検討し，次の成績を得た。

（1）反回神経治殆んどすべて搌頭外で分岐し，二分岐 $67 \%$ ，三分枝 $27 \%$ ，四分岐 $5 \%$ で，分岐しないものは 谨か $1 \%$ である、いずれの分岐形式に和いても前枝は運 動枝，後枝は知覚枝，即ち Galen 吻合枝である. 三分 岐の場合の中枝は運動枝，知覚枝いずれの場合もあり， 四分枝の場合の第 1 中枝は運動枝 (外転筋枝)，第二中 枝性知賞枝である。これらの分岐は，輸状咽頭筋下緑よ り下方 $1.5 \mathrm{~cm}$ 以内で起る場合が多い.

（2）反回神経は，甲状腺葉の墨側を走る場合が $51 \%$ ， 葉の後緑に接して走る場合が $32 \%$ で葉の後縁から離れ て走る場合は $17 \%$ に過ぎない，反回神経が甲状腺と密 接関係するのは多くは甲状腺葉の下方 $2 / 3$ の部分， 久, 見方を变えると甲状腺葉下端より上方 $3 \mathrm{~cm}$ 以内に 峈いてである。

（3）反回神経が 下甲状腺動脈の前を走るもの $12 \%$ ，

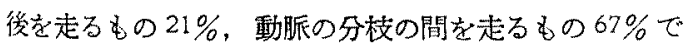
ある.

\section{文献}

1) King, B.T et al: An anatomical reason for the various behaviors of paralyzed vocal cords. Ann. of Otorhinolaryng. $57 ; 925,1948$. 2) Williams, A.F.: The nerve supply of the laryngeal muscles. J. of Laryng. 65; 343, $1951 . \quad$ 3) Rustad, W.H. et al.: Revised anatomy of the recurrent laryngeal nerves. Surgical importance based on the dissection of 100 cadavers. A preliminary report. Laryngoscope. $62 ; 237,1952 . \quad$ 4) Morison, L.F.: Recurrent laryngeal nerve paralysis. A revised conception basis on the dissection of one hundred cadavers. Ann. of Otorhinolaryng. 61;567, 1952. 5) Denecke: Kirschner's operationslehre. 1953. 6) Williams, A.F.: The recurrent laryngeal nerve and thyroid gland. J. of Laryng. 68; 719, 1954.7 7) Novotony, O.: Über die Ergebnisse der Laterofixation bei beiderseitiger Recurrensparese. Wien Klin. Wschr. 1955；144. Zbl. 53；109 より引用.

8) Young, N.: Treatment of bilateral abductor palsy of the larynx. J. of Laryng. $69 ; 390,1955.9$ 9) Pichler et al: The clinical significance of the ramification of the recurrent laryngeal nerves. A critical anatomical study. Laryngoscope. 67; 105, 1957 . 10) Arnold, G.E.: Zur Frage der Stimmlippenstellung bei Recurrenslähmung. Mschr. f. Ohrenheilk. usw. 92 : 235, 1958. 11) 広瀬：喉頭の末梢神経支配について 一その文献的展望一，耳展，4:236，1961。12）高濑, 外：我が教室に敌ける颔声の統計的観察, 特に反回神 経麻疩の統計的考察, 久留米医学会雑誌，27：731, 1964.

終りに臨み，研究材料の提供を受けた本学解 剖学, および病理学教室に謝意を表する。 本諭文の要旨は昭和 39 年 2 月 23 日，第 301 回日耳鼻九州地方会に拈いてロ演した。

（原徬到着=昭和 40.1 .11日) 